\title{
Relationship between Learning Styles \& Academic Achievement in Mathematics of Grade 8 Students
}

\author{
Ana-Mary Lorenzo Villajuan
}

\begin{abstract}
The study was conducted to find out the learning styles of the 179 Grade 8 students as correlates of their academic achievement in mathematics. The student respondents were enrolled in Palayan City National High School in Nueva Ecija during S.Y. 2018-2019.

The findings of the study showed that: the students' average academic achievement was 87.4, which was interpreted as Approaching Proficiency (Satisfactory). In terms of learning styles, students were the mostly divergent type of learners. The learning style of the respondent is significantly related to academic achievement. Assimilator learners have better academic achievement than other learners with different learning styles.
\end{abstract}

Keywords-Academic achievement, accomodator, assimilator, converger, diverger, learning styles.

\section{INTRODUCTION}

"Every student is unique in his or her strengths and challenges, and it is the job of the teacher to foster highly individualized learning in response to the student-learners [1]."

All student-learners bring into the world their individuality and uniqueness shaped through the years of schooling. Palayan City National High School is an educational institution that aimed to promote academic excellence and to recognize individual differences in the needs of every learner. Learner's academic performance is closely monitored by the teachers to identify early intervention programs for those who performed below the average. It is a process where a learner's success in school is measured to determine how their achievement fair with others. It is also a way for teachers to observe how their students learn to adjust their teaching styles to cater to the learning needs of the students.

Learning is defined as a relatively permanent change in behavior that occurs as a result of experience [2]. Learning can occur in any place where an individual experience stimulations from the environment, although it can be affected and influenced by several factors that either facilitate or hinder the learning process. One of the factors is the learning styles of the students.

The term "learning styles" is being used in educational literature since the 1970 s. It has been used synonymously with cognitive style and thinking style. Learning styles are defined as the particular way in which a learner tries to learn something and perform better on undertakings which match their preferences. Therefore, "it is important for teachers to be aware of their students' preferred styles to take advantage of opportunities to maximize student learning [3] as cited by the authors in [4].

According to Curry, till now, 21 models of learning styles have been researched in educational literature [5].

Among the 21 models, the researcher picked the learning styles concepts popularized by David Kolb. Kolb explains experiential learning theory as a combination of perception, cognition and behavior, which provides a holistic and integrative perspective on a person's approach to learning [6]. Kolb further stated, "that the learning style of the students must comprise different abilities. To enhance the effectiveness of learning styles, the learners should be able to combine at least two abilities to form their learning styles [6]". Kolb presented four types of learning styles' combining two or more abilities under each style: a. Diverging Styles (CE/RO), b. Assimilating (AC/RO), c. Converging (AC/AE) and d. Accommodating (CE/AE) [7].

Due to traditional instructions employed by some teachers, many students find it difficult to adapt to learning environments that, in some situations, have conflicted with their learning style systems [8]. This is also the general concern of teachers in Palayan National high school, especially those teaching Mathematics subjects. Since few types of research have done in the area of learning styles of students towards mathematics, this research was undertaken to add to the existing body of knowledge especially in this era of $\mathrm{K}$ to 12 education. It aimed to describe the learning styles of students in Mathematics 8 and its relationship to their academic achievement. Findings of the study provided insights to the researcher in developing an action plan that 
could cater to the learning problems encountered by the students. Thus, this research finds meaning and relevance.

\section{METHODOLOG Y}

This study utilized descriptive-correlational research design. Descriptive research was concerned with conditions, practices, differences or relationships that exist, opinions held, processes that are going on or trends that are evident [9] while according to [10] as mentioned by the authors in [11] and [12], "correlational research is employed to test the degree of relationship between two variables".

The 179 respondents of this study were chosen purposively based on the following criteria [13]: they should be Grade 8 students; enrolled at Palayan City National High School; and belonged to special science and program classes.

The researcher used a questionnaire checklist for the gathering of data. The questionnaire was divided into two (2) parts. Part I of the questionnaire was designed to gather information on the socio-demographic profile of the respondents. Part II of the instrument was focused on the learning styles of the students and patterned after the learning styles inventory of Kolb [6].

The data gathered were statistically treated using frequency, percentage, weighted mean and correlation formulas. All computations were done using Microsoft Excel and Statistical Package for Social Sciences (SPSS) version 17.

\section{RESULTS AND DISCUSSION}

\section{Learning Styles of the Respondents}

Table 1 presents the learning styles of Grade 8 students in Mathematics as to Kolb's Learning Styles in terms of as similator, divergent, accommodator and convergent.
Table 1. Learning Styles of the Respondents

\begin{tabular}{l|c|c}
\hline Learning Styles & Frequency & Percent \\
\hline Assimilators & 36 & 20.11 \\
\hline Divergent & 88 & 49.16 \\
\hline Accommodators & 22 & 12.29 \\
\hline Convergent & 33 & 18.44 \\
\hline Total & 179 & 100.00 \\
\hline
\end{tabular}

Results show that among 179 respondents there are 88 divergent which is 49.16 percent of the respondents, 36 or 20.11 percent respondents are assimilators while 33 or 18.44 percent of them are convergent and 22 or 12.29 percent are accommodators.

The data suggest that most of the student respondents are divergent and the least are accommodators. According to [14], "People with diverging learning styles have broad cultural interests and like to gather information. They are interested in people, tend to be imaginative and emotional, and tend to be strong in the arts. People with the diverging style prefer to work in groups, to listen with an open mind and to receive pers onal feedback".

Only $12.29 \%$ are accommodators. This implies that accommodator learners in Palayan City are minimal. People with an Accommodating learning style will tend to rely on others for information than carry out their analysis. They set targets and actively work in the field, trying different ways to achieve an objective [14].

\section{Academic Achievement in Mathematics}

The table shows the academic achievement of the respondents in terms of their grade in Mathematics.

Table 2. Academic Achievement of Grade 8 Students in Mathematics

\begin{tabular}{c|c|c|c}
\hline Grade in Math & Frequency & Percentage & Descriptors \\
\hline 95 and above & 5 & 2.79 & Advanced(Outstanding) \\
\hline 90 to 94 & 38 & 21.23 & Proficient(Very Satisfactory) \\
\hline 85 to 89 & 99 & 55.31 & Approaching Proficiency(Satisfactory) \\
\hline 80 to 84 & 37 & 20.67 & Developing(Fairly Satisfactory) \\
\hline 75 to 79 & 0 & 0.00 & Beginning(Did Not Meet Expectations) \\
\hline Total & $\mathbf{1 7 9}$ & 100.00 & \\
\hline Mean & \multicolumn{2}{|c|}{} & Approaching Proficiency(Satisfactory) \\
\hline
\end{tabular}

It is shown that 99 respondents $(55.31 \%)$ got grades of $85-$ 89 (Satisfactory). Another group of 38 (21.23\%) received the grades of 90-94 (Very Satisfactory). Thirty-seven (37) students $(20.67 \%)$ earned the grades of 80-84 (Fairly Satisfactory) while $5(2.79 \%)$ respondents received the highest grades of 95-100 (Outstanding). Nobody from the 
respondents got the grades of $75-79$ (Did not meet expectations).

It can also be noted on the table that on the average, the respondents' performance was at the satisfactory level or in the approaching proficiency level. This finding is similar to the result of the study of the researcher in [15] that the performance in General Mathematics of senior high school respondents was average or satisfactory. Nonetheless, it contradicts the findings of [16] regarding the mathematical competency and performance in Mathematics of 320 grade 11 students, which revealed a below proficiency level in Mathematics of her respondents. Further, the research done by [17], concerning the Mathematics performance of Grade 8 students in the $\mathrm{K}$ to 12 curriculum does not conform with this finding. "They found out that most of the respondents were in the beginning level of achievement only."

\section{Relationship between the Learning Styles and Academic Achievement}

Table 3 presents the relationship between the learning styles of the respondents and their academic achievement.

Table 3. Relationship between the Learning Styles and

\begin{tabular}{c|l|c}
\multicolumn{3}{c}{ Academic Achievement } \\
\hline & Academic & Achievement \\
\hline Variable & r-value & p-value \\
\hline Learning Style & $-.171^{*}$ & .022 \\
\hline Interpretation & Significant relationship \\
\hline correlation is significant @ 0.05 level
\end{tabular}

Learning styles of the respondents were significantly related to their academic achievement. The negative sign of the value of $r$ means that assimilators have better academic achievement in mathematics than the other learning styles, especially to the divergent styles of learners.

It is clearly understood that assimilators have higher mathematics achievement than in any learning styles because the characteristics of these learners are for mathematics discipline. The Assimilating learning preference is for a concise, logical approach. People with this style are more attracted to logically sound theories than approaches based on practical value [14]. This learning style of people is important for effectiveness in information and science careers. In formal learning situations, people with this style prefer readings, lectures, exploring analytical models, and having time to think things through [18].

\section{CONCLUSIONS AND} RECOMMENDATIONS

Most of the respondents were divergent learners. Their grades in Mathematics fall to Approaching Proficiency level. Assimilator respondents have better academic achievement than other type of learners. In the light of the findings and conclusions of the study the following are recommended: a. learning activities and different approaches that are a very unique and very effective method in providing meaningful, enjoyable and engaging experience [19] should be provided by teachers to the learners to improve their grades to outstanding level; $b$. interventional activities should be employed by teachers in teaching mathematics according to the learning styles of the learners to make them more motivated to learn. c. educational or curriculum planners should consider the learning styles of the students in making plans to achieve high performance of the students. They can also make curriculum revision to fit the learning styles of the secondary students; and d. lastly, future researches, of similar nature are recommended, such as looking into the relationship of learning styles with teaching styles.

\section{REFERENCES}

[1] Brandenberger, Ellen. (2014). Daily Edventures., http://daily edventures.com/index.php/2014/08/18/ellenbrand enberger/

[2] SACE Board.(2010). Skills and Applications Task Learning. South Australia.

[3] "Thinking Styles: Keys to Understanding Student Performance" Phi Delta Kappan January 1990 pp.366371.Published in ERN May/June 1990 Volume 3, Number 3.

[4] Subia, G.S., Trinidad, C.L., Pascual, R.R., Medrano, H.B. \& Manuzon, E.P.(2019). Learning Styles and Preferred Teaching Styles of Master of Arts in Teaching (MAT), major in Vocational Technological Education (VTE) Generarion Y Learners. International Journal of English Literature and Social Sciences (IJELS) .Vol-4, Issue 2, MarApr, 2019. https://dx.doi.org/10.22161/ijels.4.2.35.

[5] Bank, B. (2007) Gender and education: An encyclopedia (Vol.1) Westport, Connecticut: Praeger Publishers.

[6] Kolb, D. (2009). The learning way: Meta-cognitive aspects of experiential learning. Simulation and Gaming, 40(3), 297

[7] Naqvi A, Naqvi F (2017) A Study on Learning Styles, Gender and Academic Performance of Post Graduate Management Students in India. Int J Econ Manag Sci 6: 398. doi: 10.4172/2162-6359.1000398

[8] Jones, C., Reichard, C. \& Mokhtari, K. 2003. Are students' learning styles discipline spesific?.Community College Journal of Research and Practice, 27 
[9] Creswell, J. W. 2007. Educational Research, Planning, Conducting, and Evaluating Quantitative and Qualitative Research, University of Netvaska : Merrill Prentice Hall.

[10] Patten, M.L.(2002). Understanding Research Methods. Pyrczak Publishing, U.S.A.

[11] Subia, G., Salangsang, L. and Medrano, H.(2018).Attitude and Performance in Mathematics of Elementary Education Students: A correlational Analysis. AmericanScientific Research Journal for Engineering, Technology and Sciences (ASRJETS), 39, 206-213.

[12] Subia, G., Amaranto, J., Amaranto, J.,Bustamante, J. and Damaso, I.(2019). Chess and Mathematics Performance of College Players: An Exploratory Analysis. Open Access Library Journal, 6, 1-7. doi:10.4236/oalib.1105195

[13] Subia, G.S. (2018). Comprehensible Technique in Solving Consecutive Number Problems in Algebra. Journal of Applied Mathematics and Physics, 6,447-457. https://doi.org/10.4236/jamp.2018.63041

[14] Mcleod, Saul. (2017). Kolb's Learning Styles and Experiential Learning Cycle. https://www.simply psy chology .org/learning-kolb.html

[15] Marcos, M.(2018). Entry competencies and performance in mathematics of Engineering students in State Technological Universities in Region III.(Doctoral Dissertation). Nueva Ecija University of Science and Technology, Graduate School, Cabanatuan City, Philippines.

[16] Damaso, I.(2017). Mathematics competency and performance in general mathematics of grade 11 students in selected public and private high schools (Master's Thesis). Nueva Ecija University of Science and Technology, Graduate School, Cabanatuan City, Philippines.

[17] Capate, R. \& M.Lapinid. (2015). Assessing the mathematics performance of grade 8 students as basis for enhancing instruction and aligning with $\mathrm{k}$ to 12 curriculum. DLSU Research Congress, De La Salle University, Manila, Philippines. March 2-4, 2015.

[18] Businessballs. (2019). Kolb's learning styles. https://www.businessballs.com/self-awareness/kolbslearning-sty les/

[19] Subia, Gener S. (2018). Think Like My Teacher (TLMT): A New Method in Assessing Millennial Learners. International Journal of Arts, Humanities and Social Sciences. Volume 3. Issue 1.www.ijahss.com 